Check for updates

Cite this: RSC Adv., 2017, 7, 41819

Received 20th August 2017 Accepted 23rd August 2017

DOI: $10.1039 / c 7 r a 09207 e$

rsc.li/rsc-advances

\title{
Zinc bimetallics supported by a xanthene-bridged dinucleating ligand: synthesis, characterization, and lactide polymerization studies $\uparrow$
}

\author{
Thilini S. Hollingsworth, ${ }^{a}$ Ryan L. Hollingsworth, ${ }^{a}$ Tomer Rosen ${ }^{\star b}$ \\ and Stanislav Groysman (D) *a
}

\begin{abstract}
A new, potentially dinucleating xanthene-bridged bis(iminophenolate) ligand $L\left(L=6,6^{\prime}-\left(\left(1 E, 1^{\prime} E\right)-((2,7-\right.\right.$ di-tert-butyl-9,9-dimethyl-9H-xanthene-4,5-diyl)bis(azanylylidene))bis(methanylylidene))bis(2,4-di-tertbutylphenol)) has been synthesized and its coordination chemistry with zinc precursors featuring alkoxide, chloride, and ethyl leaving groups has been investigated. The reaction of a zinc precursor bearing two bulky alkoxides, $\mathrm{Zn}(\mathrm{Cl})\left(\mu^{2}-\mathrm{OR}\right)_{2} \mathrm{~L}(\mathrm{THF})(\mathrm{OR}=$ di-tert-butyl-phenylmethoxide), formed a mononuclear complex $\mathrm{Zn}(\mathrm{L})$ that was isolated as an $\mathrm{H}$-bond adduct with $\mathrm{HOR}, \mathrm{Zn}(\mathrm{L}) \cdot \mathrm{HOR}$. In contrast, the reaction of $\mathrm{L}$ (or its lithium salt) with diethylzinc (or zinc chloride) led to the formation of the corresponding dinuclear complexes $\mathrm{Zn}_{2}(\mathrm{~L})(\mathrm{Et})_{2}$ and $\mathrm{Zn}_{2}(\mathrm{~L})\left(\mu^{2}-\mathrm{Cl}_{4} \mathrm{Li}_{2}\left(\mathrm{OEt} \mathrm{t}_{2}\right)_{2}\right.$. X-ray crystallography revealed syn-parallel geometry for $\mathrm{Zn}_{2}(\mathrm{~L})(\mathrm{Et})_{2}(\mathrm{Zn} \cdots \mathrm{Zn}$ distance of $4.5 \AA)$ and anti-parallel geometry for $\mathrm{Zn}_{2}(\mathrm{~L})\left(\mu^{2}-\mathrm{Cl}_{4} \mathrm{Li}_{2}\left(\mathrm{OEt}_{2}\right)_{2}(\mathrm{Zn} \cdots \mathrm{Zn}\right.$ distance of $6.7 \AA ̊ \AA) . Z \mathrm{n}_{2}(\mathrm{~L})(\mathrm{Et})_{2}$ was found to be somewhat unstable, demonstrating decomposition into $\mathrm{Zn}(\mathrm{L})$ and $\mathrm{ZnEt}_{2}$; this decomposition can be reversed by the addition of excess $\mathrm{ZnEt}_{2}$. Treatment of $\mathrm{Zn}_{2}(\mathrm{~L})(\mathrm{Et})_{2}$ with benzyl alcohol $(\mathrm{BnOH})$ in deuterated benzene, toluene, or dichloromethane resulted in the formation of $\mathrm{Zn}_{2}(\mathrm{~L})(\mathrm{OBn})_{2}$, which was characterized by ${ }^{1} \mathrm{H}$ and ${ }^{13} \mathrm{C}$ NMR spectroscopy. $\mathrm{Zn}_{2}(\mathrm{~L})(\mathrm{OBn})_{2}$ was found to be active in the ring-opening polymerization of rac-lactide to afford heterotactically inclined PLA.
\end{abstract}

\section{Introduction}

Bimetallic cooperativity is a common theme in biological catalysis, ${ }^{1}$ and is currently an active area of research in chemical catalysis. ${ }^{2,3}$ Among other fields, bimetallic cooperativity has been postulated in polymerization of lactide and other cyclic esters. Lactide is a cyclic diester that is derived from renewable sources. ${ }^{4}$ The corresponding polymer, poly(lactic acid), features many characteristic properties similar to those of polyolefins, but offers an important advantage of biodegradability. ${ }^{5}$ Lactide polymerization is generally catalyzed by strongly Lewis-acidic metals, in particular zinc. ${ }^{6,7}$ The structure of the metal catalyst affects the properties of the resulting poly(lactic acid), including tacticity, molecular weight, and molecular weight distribution. Several recent reports demonstrated advantageous reactivity of predesigned bimetallics ${ }^{8-16}$ that may exhibit higher catalytic

${ }^{a}$ Department of Chemistry, Wayne State University, 5101 Cass Ave, Detroit, MI, 48202, USA. E-mail: groysman@chem.wayne.edu

${ }^{b}$ School of Chemistry, Raymond and Beverly Sackler Faculty of Exact Sciences, Tel-Aviv University, Tel-Aviv 69978, Israel. E-mail: tomer.rsn@gmail.com

$\dagger$ Electronic supplementary information (ESI) available: NMR spectra, crystal and refinement data for compounds L, 1-5, 7, and 8. CCDC 1554332-1554340. For ESI and crystallographic data in CIF or other electronic format see DOI: 10.1039/c7ra09207e activity, higher molecular weights, or improved tacticity, in comparison with related mononuclear species. The observed synergism of predesigned bimetallics is corroborated by the interesting observation that bimetallic alkoxide-bridged active sites may be preferential even for precursors lacking dinucleating ligands. ${ }^{17}$ Thus, Mehrkhodavandi and coworkers have recently demonstrated that a di-indium complex, bridged by a monodentate alkoxide (Fig. 1), retains its dinuclear structure in solution and functions as a bimetallic polymerization catalyst. ${ }^{17}$

As the reactivity of bimetallic catalyst depends on the metalmetal separation, there is a growing interest in bimetallic catalysts where a fixed metal-metal distance is enforced by a sufficiently rigid dinucleating ligand. ${ }^{2}$ There is a significant number of bimetallic lactide polymerization catalysts stabilized by dinucleating ligands, including Salen derivatives, ${ }^{13}$ 2,6-diaminophenolate derivatives, ${ }^{\mathbf{8}, 9 b, 16} \quad 2,2^{\prime}$-phenolate derivatives, ${ }^{10}$ and other systems (for selected examples see Fig. 1). Our group investigates cooperative reactivity of bimetallics supported by dinucleating ligands exhibiting various degrees of rigidity. ${ }^{18}$ $\mathrm{We}$, and others, have recently begun investigating potentially dinucleating ligands based on 4,5-diamino xanthene linkers. ${ }^{19,20}$ Xanthene linker positions two metals sufficiently close to each other to allow cooperative reactivity. Yet, the openchain nature of xanthene-bridged bis(iminopyridine) ligands, 
${ }^{t} \mathrm{Bu}$

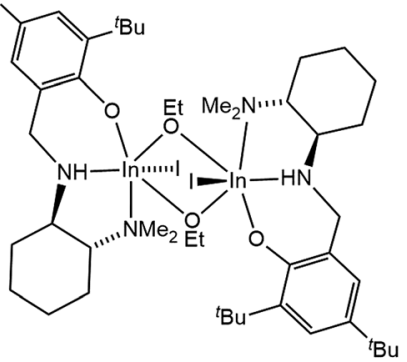

Mehrkhodavandi and coworkers

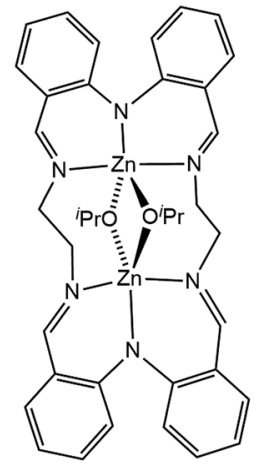

Brooker, Williams and coworkers

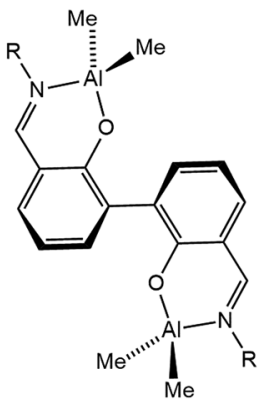

Carpentier, Kirillov and coworkers

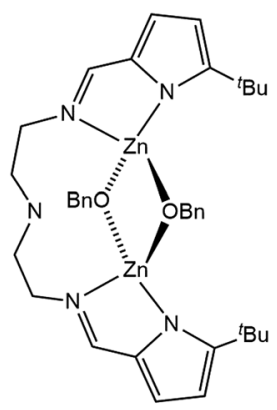

Wang and coworkers

Fig. 1 Selected recently reported bimetallic pre-catalysts for lactide polymerization. ${ }^{9-11,17}$

coupled with single $\mathrm{C} 4-\mathrm{N}$ and $\mathrm{C} 5-\mathrm{N}$ bonds, allow the two chelating units sufficient freedom of movement versus each other, which may be beneficial if varying metal-metal distances are required to satisfy different bimetallic reaction intermediates. Following our recent report on cooperative alkyne cyclotrimerization catalyzed by xanthene-based bis(iminopyridine) dinickel complex, ${ }^{\mathbf{1 9 b}}$ we turned to investigate the reactivity of xanthene-based di-zinc complexes in lactide polymerization. We hypothesized that neutral bis(iminopyridine) ligands would not be suitable for the relatively hard dicationic zinc(II), and thus decided to replace neutral iminopyridine with monoanionic iminophenolate. The presence of a single monoanionic chelate at each zinc centre enables coordination of an additional monoanionic monodentate ligand (alkoxide or amide), as required for an active lactide polymerization catalyst. Herein we describe coordination chemistry of the new xanthenebridged bis(iminophenolate) ligand with zinc, and present the reactivity of the resulting bimetallic complexes in lactide polymerization.

\section{Results and discussion}

Ligand synthesis

Dinucleating ligand $\mathbf{L}$ was obtained by condensation of previously reported 2,7-di-tert-butyl-9,9-dimethyl-4,5-diaminoxanthene $^{20}$ with 3,5-di-tert-butyl-2-hydroxybenzaldehyde in

methanol. Pure ligand was obtained by recrystallization from benzene/methanol as bright yellow crystals in 76\% yield. NMR data for $\mathbf{L}$ is consistent with the single species in solution featuring effective $C_{2 \mathrm{v}}$ symmetry as indicated by one peak for both xanthene methyl groups, and one peak for both xanthene tert-butyl peaks. Interestingly, two different types of crystals were obtained by recrystallization of analytically- and NMR-pure sample of $\mathbf{L}$ from hexanes (see ESI for details $\dagger$ ). The major difference between the structures ( $\mathbf{L}^{\text {syn }}$ and $\mathbf{L}^{\text {anti }}$ ) is in the relative disposition of the chelating units - iminophenolates. In $\mathbf{L}^{\text {syn }}$, the phenolates are on the same side of xanthene linker, which leads to their syn-parallel arrangement. In $\mathbf{L}^{\text {anti }}$, the phenolates are on two different sides of the xanthene linker, in the anti-parallel arrangement. One noteworthy feature of the structures is the flexibility of the xanthene linker. While the linker appears to be perfectly flat in $\mathbf{L}^{\text {syn }}$, it is slightly puckered in $\mathbf{L}^{\text {anti }}$.

\section{Complex synthesis and characterization}

Metal-alkoxide complexes constitute the most commonly used form of precatalysts for lactide polymerization. We have previously described series of divalent $3 \mathrm{~d}$ metal complexes of the $\mathrm{M}(\mathrm{OR})_{2}(\mathrm{THF})_{2}$ form (OR $\left.=\mathrm{OC}^{t} \mathrm{Bu}_{2} \mathrm{Ph}\right)$, whose monomeric structure was made possible by the use of excessively bulky alkoxides. $^{21,22}$ One could postulate that a zinc complex of similar form could provide an ideal precursor for the reaction with $\mathbf{L}$, as: (1) phenols are significantly more acidic than alcohols; (2) a bulky alkoxide should render zinc centres in a hypothetical " $\mathrm{Zn}_{2}(\mathbf{L})(\mathrm{OR})_{2}$ " complex coordinatively unsaturated and therefore highly reactive toward monomer insertion. Thus, our initial route towards bimetallic zinc complexes with $\mathbf{L}$ targeted synthesis of a " $\mathrm{Zn}(\mathrm{OR})_{2}(\mathrm{THF})_{2}$ " species first. The addition of two equivalents of $\mathrm{ROH}^{22 d}$ to diethylzinc failed to produce the

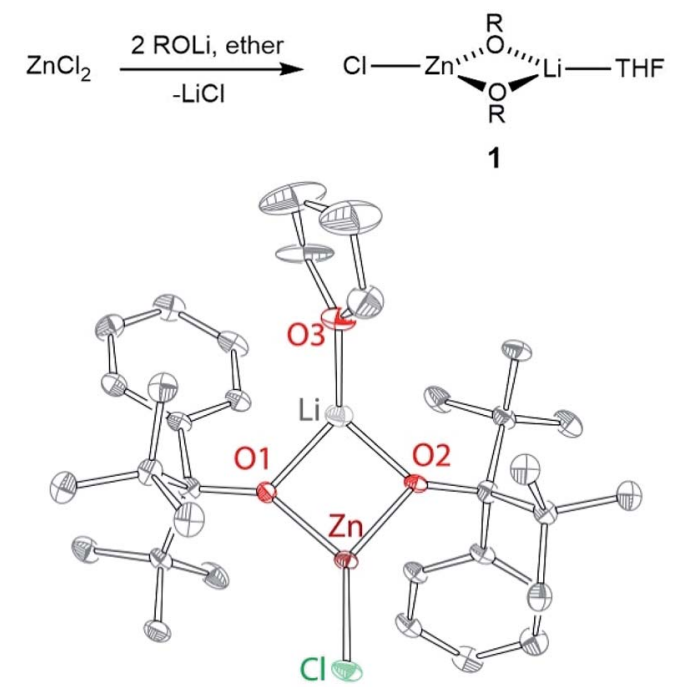

Fig. 2 Top: synthesis of compound 1; OR $=\mathrm{OC}^{t} \mathrm{Bu}_{2} \mathrm{Ph}$. Bottom: X-ray structure of $1,50 \%$ probability ellipsoids. Selected bond distances ( $\AA$ ) and angles $\left({ }^{\circ}\right.$ ): $\mathrm{Zn} \mathrm{Cl} 2.155(1), \mathrm{Zn} \mathrm{O} 1$ 1.902(3), Zn O2 1.914(3), O1 Zn Cl 130.5(1), O2 Zn Cl 137.7(1), O1 Zn O2 89.6(1). 
expected zinc-alkoxide product. Intriguingly, no reaction was observed by ${ }^{1} \mathrm{H}$ NMR spectroscopy, suggesting that our alkoxide ligand may be more basic than alkyl (ethyl) ligand in the zinc coordination environment. Salt metathesis reaction between zinc chloride and two equivalents of ROLi produced $\mathrm{Zn}(\mathrm{Cl})\left(\mu_{2^{-}}\right.$ $\mathrm{OR})_{2} \mathrm{Li}(\mathrm{THF})(\mathbf{1})$, which was isolated as colourless crystals from hexanes in $75 \%$ yield. The synthesis and structure of $\mathbf{1}$ are given in Fig. 2, along with the corresponding bond distances and angles. 1 demonstrates distorted trigonal planar zinc centre ligated by two OR ligands and one chloride. ${ }^{23}$ Notably, the chloride is terminal while the alkoxides are bridging. In contrast, in the corresponding nickel(II) structure $\left(\mathrm{Ni}(\mathrm{OR})\left(\mu_{2}-\right.\right.$ $\left.\mathrm{Cl})\left(\mu_{2}-\mathrm{OR}\right) \mathrm{Li}(\mathrm{THF})_{2}\right)$, the chloride was bridging while one of the alkoxides was terminal. ${ }^{24}$ The bridging nature of both alkoxides in $\mathrm{Zn}(\mathrm{Cl})\left(\mu_{2}-\mathrm{OR}\right)_{2} \mathrm{Li}(\mathrm{THF})$ supports the notion of the increased alkoxide basicity when coordinated to zinc.

To abstract LiCl from 1, it was treated with $\mathrm{TlPF}_{6}$ or $\mathrm{AgPF}_{6}$. In both cases, an immediate reaction was observed, as indicated by the formation of $\mathrm{TlCl}$ (or $\mathrm{AgCl}$ ) precipitate. However, while ${ }^{1} \mathrm{H}$ NMR spectrum of the isolated product suggested formation of " $\mathrm{Zn}(\mathrm{OR})_{2}$ " species, it was also accompanied by the formation of free alcohol, $\mathrm{ROH}$. Our numerous attempts to isolate pure " $\mathrm{Zn}(\mathrm{OR})_{2}$ " by recrystallization led to product mixtures containing varying amounts of the protonated ligand $\mathrm{ROH}$. We note that while this behaviour stands in contrast to the $\mathrm{Cr}(\mathrm{II}), \mathrm{Mn}$ (II), $\mathrm{Fe}(\mathrm{II})$, and $\mathrm{Co}(\mathrm{II})$, for which $\mathrm{M}(\mathrm{OR})_{2}(\mathrm{THF})_{2}$ could be isolated in good yields following similar protocols, ${ }^{24,22 a} \mathrm{Ni}(\mathrm{II})$ and $\mathrm{Cu}(\mathrm{II})$ also failed to lead to isolable $\mathrm{M}(\mathrm{OR})_{2}(\mathrm{THF})_{2}$ complexes. $^{24}$

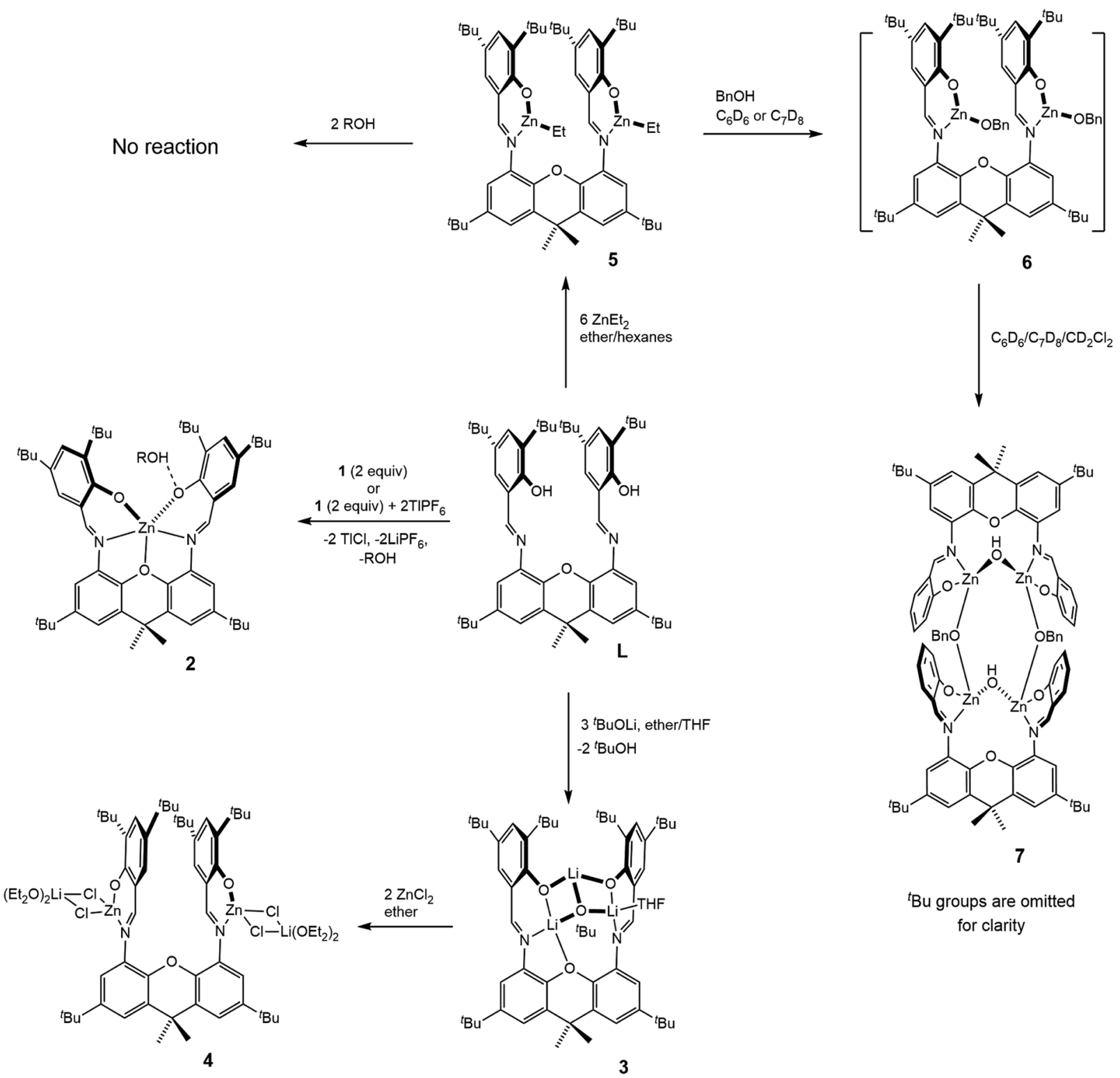

Scheme 1 Coordination chemistry of $L$ with zinc described in this manuscript. Complex in square brackets (6) was not characterized by $X$-ray crystallography, and its structure is proposed based on NMR spectroscopy. 
As we could not isolate pure " $\mathrm{Zn}(\mathrm{OR})_{2}$ ", we investigated the reactivity of $\mathbf{L}$ with two equivalents of complex $\mathbf{1}$, or with " $\mathrm{Zn}(\mathrm{OR})_{2}$ " prepared in situ. Slow addition of $\mathbf{L}$ to the cold $(-35$ $\left.{ }^{\circ} \mathrm{C}\right)$ THF solution containing two equivalents of complex 1 led to the clean formation of mononuclear complex 2 (Scheme 1). Similarly, addition of $\mathbf{L}$ to the mixture of $\mathbf{1}$ and two equivalents of $\mathrm{TlPF}_{6}$ led to the formation of complex 2 . It is hypothesized that the inability of $\mathbf{L}$ to function as a dinucleating ligand in this case results from the basicity of zinc-alkoxide precursors. It is also possible that the steric bulk of the Zn-OR fragment, occupying one of the $\mathbf{L}$ sites, prevents the reaction of the second site with another equivalent of $\mathbf{1}$, triggering instead intramolecular protonolysis. In support of this hypothesis, complex 2 was obtained as an $\mathrm{ROH}$ adduct, $2 \cdot \mathrm{HOR}$, both in solution and in solid state. Solid-state structure of 2 (Fig. 3) indicates hydrogen bonding between one of the $\mathbf{L}$ phenolates and the hydrogen atom of $\mathrm{ROH}(2.13 \AA)$.

As the direct reaction of a zinc alkoxide precursor did not yield the desired dinuclear bis(alkoxide) complex, salt metathesis route of deprotonated $\mathbf{L}$ was pursued. Treatment of $\mathbf{L}$ with approximately two equivalents of ${ }^{t} \mathrm{BuOLi}$ produced compound 3, which was obtained as yellow microcrystalline solid by recrystallization from hexanes. X-ray quality crystals of 3 were obtained from ether, and the solid-state structure is presented in Fig. 4. Compound $\mathbf{3}$ is a dilithium salt of $\mathbf{L}$ that incorporates an additional equivalent of $\mathrm{LiO}^{t} \mathrm{Bu}$ to form the $\left[\mathrm{Li}_{3} \mathrm{O}_{3}\right]$ cluster, in which lithiums are bridged by the $\mu^{3}-\mathrm{O}^{t} \mathrm{Bu}$ ligand. In the solidstate structure, all lithium sites are different, two being tetracoordinate and the third tri-coordinate (Fig. 4). One of the tetra-coordinate lithium sites is ligated by an ether molecule. The ${ }^{1} \mathrm{H}$ NMR spectrum of 3 (obtained from hexanes) is in general agreement with this structure, with the major difference being coordinated THF in place of ether observed in the solidstate structure. A singlet for the $\left[\mathrm{O}^{t} \mathrm{Bu}\right]$ group is observed at

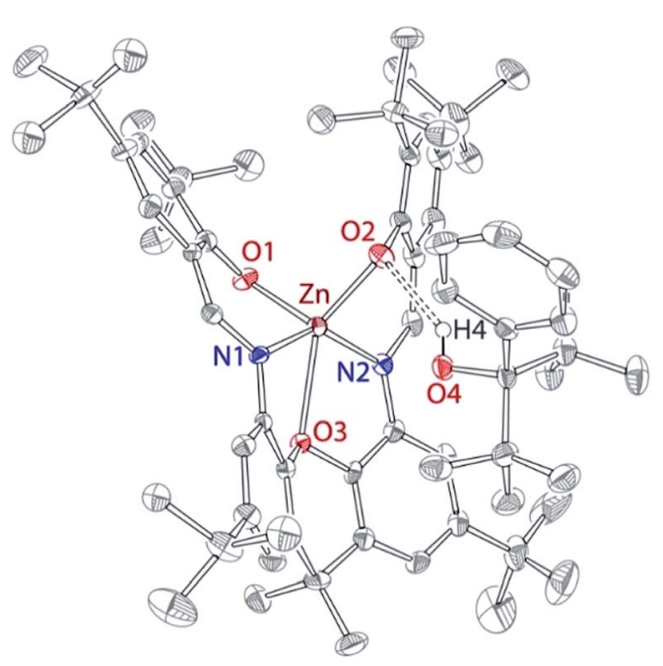

Fig. 3 X-ray structure of $2 \cdot \mathrm{HOR}, 50 \%$ probability ellipsoids. $\mathrm{H}$ atoms (except for $\mathrm{H} 4$ ), co-crystallized solvent, and alternative conformation of ${ }^{t} \mathrm{Bu}$ groups are omitted for clarity. Selected bond distances $(\AA \AA)$ : $Z n$ O1 1.938(3), Zn O2 1.979(3), Zn N1 2.007(3), Zn N2 2.037(3), Zn O3

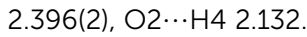

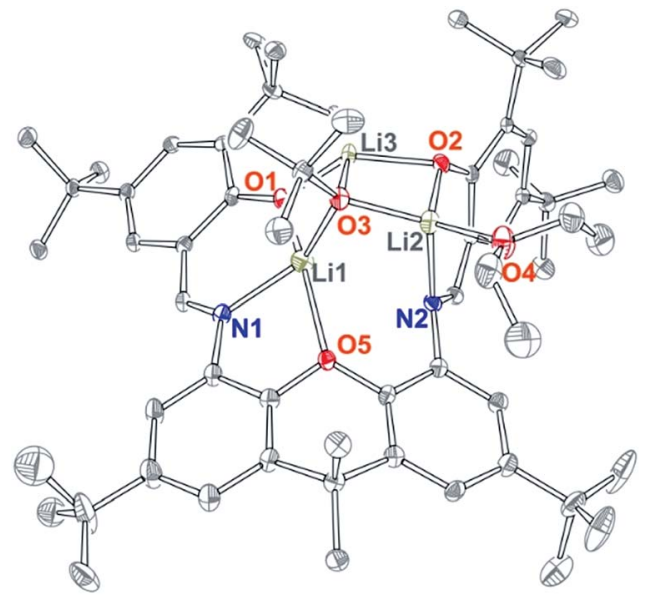

Fig. 4 X-ray structure of 3, 30\% probability ellipsoids. $\mathrm{H}$ atoms, cocrystallized solvent, and alternative conformation of ${ }^{t} \mathrm{Bu}$ groups are omitted for clarity.

$1.34 \mathrm{ppm}$. The two iminophenoxide chelates are different in solid state but equilibrate in solution, giving rise to five different aromatic signals, two different signals for the phenoxide ${ }^{t} \mathrm{Bu}$ groups, and one signal for the xanthene ${ }^{t} \mathrm{Bu}$ groups. In contrast, xanthene methyls give rise to two different signals (1.77 and $1.58 \mathrm{ppm}$ ), breaking the effective xanthene plane symmetry, due to the $\mathrm{Li}_{3} \mathrm{O}_{3}$ cluster bridging the two iminophenoxide sites. The spectrum shows varying amounts of coordinated THF (one to two equivalents), whose labile coordination is likely responsible for the observed higher symmetry in solution. The attempts to use less than two equivalents of ${ }^{t} \mathrm{BuOLi}$ led to the isolation of the same structure, obtained in lower yield.

Addition of 3 to two equivalents of zinc chloride led to the formation of the dinuclear complex $\mathrm{Zn}_{2} \mathrm{Li}_{2}(\mathbf{L})\left(\mathrm{Cl}_{4}\right)\left(\mathrm{OEt}_{2}\right)_{4}$ (4).

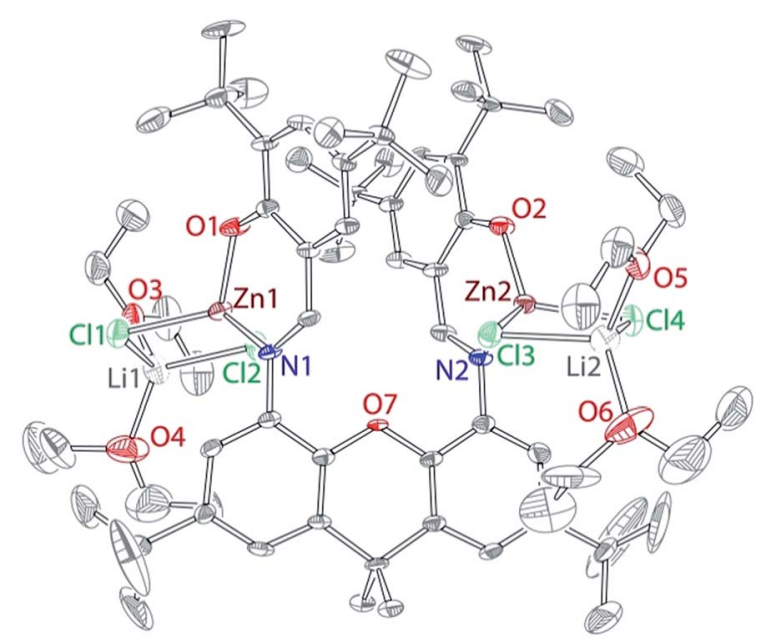

Fig. $5 \mathrm{X}$-ray structure (50\% probability ellipsoids) of 4 . Selected bond distances (Å) and angles $\left({ }^{\circ}\right)$ : Zn1 O1 1.900(3), Zn1 N1 1.989(4), Zn1 Cl1 2.269(1), Zn1 Cl2 2.268(1), Zn2 O2 1.902(3), Zn2 N2 1.987(4), Zn2 Cl3 2.262(1), Zn2 Cl4 2.271(1), O1 Zn1 N1 96.4(1), O2 Zn2 N2 96.9(1) Cl1 Zn1 Cl2 101.1(1), Cl3 Zn2 Cl4 100.9(1). 
Complex 4 was isolated as yellow blocks from a hexane/ether mixture in $43 \%$ yield. The complex was characterized by proton NMR spectroscopy, X-ray crystallography and elemental analysis. ${ }^{1} \mathrm{H}$ NMR spectrum of 4 contains broad resonances, suggesting a dynamic process. The X-ray structure of 4 is given in Fig. 5 below. The structure reveals that 4 is a di-zinc complex, where each zinc displays a pseudotetrahedral coordination environment including two chlorides, in addition to the iminophenolate chelate. The structure incorporates lithium ions that are linked to the complex through two chloride bridges each; pseudotetrahedral geometry of the lithium sites is completed by two coordinated ether molecules. Most significantly, the structure reveals anti-parallel arrangement of the two zinc metals coordinated by $\mathbf{L}$, with $\mathrm{Zn}-\mathrm{Zn}$ distance of $6.7 \AA$. While the anti-parallel arrangement is expected to be unfavourable for catalysis, it is likely due to the steric pressure around each zinc centre. We postulated that the removal of the incorporated lithium ions might release steric pressure and enable syn geometry of the zinc centres. To remove LiCl, $\mathbf{4}$ was treated with $\mathrm{TlPF}_{6}$ or $\mathrm{AgPF}_{6}$. In both cases, complex mixtures of products formed, from which we were not able to isolate any zinccontaining products. We have also attempted a direct reaction between 4 and two equivalents of LiOR, which failed to lead to a well-defined zinc-containing product.

As the attempts to obtain " $\mathrm{Zn}_{2}(\mathbf{L})(\mathrm{OR})_{2}$ " species (where OR is a bulky alkoxide $\mathrm{OC}^{t} \mathrm{Bu}_{2} \mathrm{Ph}$ ) were unsuccessful, we decided to pursue dinuclear zinc species with a more conventional alkoxide - benzyloxide, $\mathrm{Zn}_{2}(\mathbf{L})(\mathrm{OBn})_{2}$. Zinc benzyloxide complexes are commonly used as precursors in lactide polymerization. ${ }^{7}$ As the most convenient path to these species generally lies through the protonolysis of preformed zinc alkyl species, the synthesis of $\mathrm{Zn}_{2}(\mathbf{L})(\mathrm{Et})_{2}$ was pursued first. Slow addition of $\mathbf{L}$ to the excess diethylzinc solution ( 6 equivalents) led to the formation of yellow-orange $\mathrm{Zn}_{2}(\mathrm{~L})(\mathrm{Et})_{2}(5)$, that was obtained as an analytically pure solid in 95\% yield. NMR

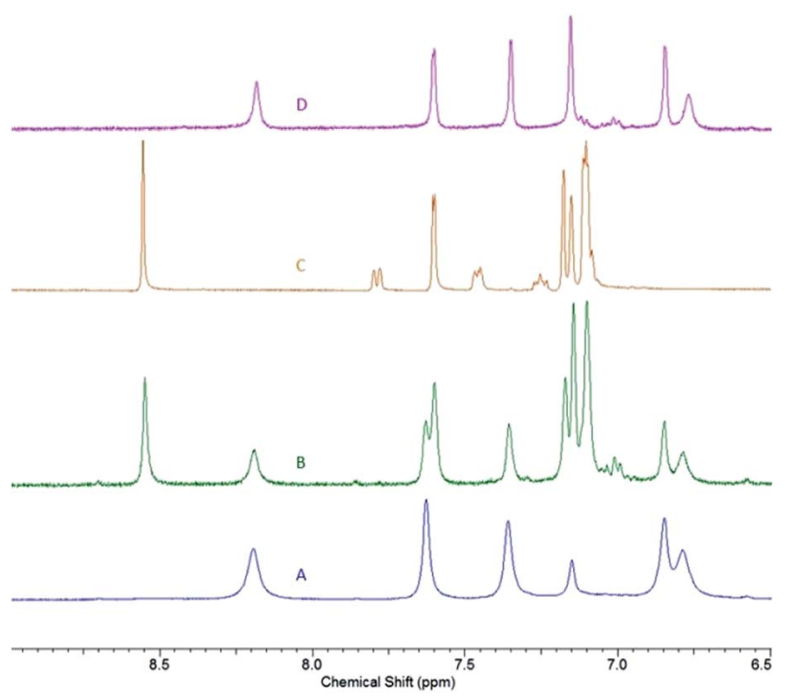

Fig. 6 Aromatic region of ${ }^{1} \mathrm{H}$ NMR spectra of: 5 at high concentration (A); 5 at low concentration (B); $2 \cdot \mathrm{HOR}(\mathrm{C}) ; 5$ at low concentration following the addition of excess $\mathrm{ZnEt}_{2}$ (D). spectrum of $\mathbf{5}$ is concentration-dependent. At high concentration ( $\sim 60 \mathrm{mM})$, a single set of peaks, albeit slightly broadened, is observed (for the aromatic region, see Fig. 6A; the full spectrum is given in ESI $\dagger$ ). The overall spectrum, that contains five distinct signals in the aromatic region, two distinct signals for the ${ }^{t} \mathrm{Bu}$ groups, and a single resonance for xanthene methyl groups, is consistent with the fluxional structure of 5. Zn$\mathrm{CH}_{2} \mathrm{CH}_{3}$ methylene appears as a broad signal at $0.64 \mathrm{ppm}$ in ${ }^{1} \mathrm{H}$ NMR spectrum. Intriguingly, low concentration $(\sim 10 \mathrm{mM})$ spectrum (Fig. 6B) indicates presence of another species, in addition to 5. Comparing the spectrum of $\mathbf{5}$ with the spectrum of $2 \cdot \mathrm{HOR}$ (Fig. $6 \mathrm{C}$ ) reveals the presence of compound 2 in a lowconcentration spectrum. One possible explanation for this observation is the dinuclear - mononuclear equilibrium that is more pronounced at low concentrations due to the volatility of $\mathrm{ZnEt}_{2}$. To probe this hypothesis, we treated the lowconcentration spectrum with excess $\mathrm{ZnEt}_{2}$ (4 equivalents), which resulted in the restoration of a single species consistent with $\mathrm{Zn}_{2}(\mathbf{L})(\mathrm{Et})_{2}$ (Fig. 6D).

X-ray quality crystals of $\mathbf{5}$ were obtained by recrystallization from ether. 5 (Fig. 7) is a dinuclear complex exhibiting synparallel disposition of the two zinc-ethyl units, with a $\mathrm{Zn} \cdots \mathrm{Zn}$ separation of $4.5 \AA$. The geometry around zincs is trigonal planar, and the xanthene linker is flat. Zinc-phenoxide, imino, and ethyl distances are unexceptional..$^{25}$ Overall, 5 constitutes a rare structure of an iminophenolate-bound zinc-ethyl in
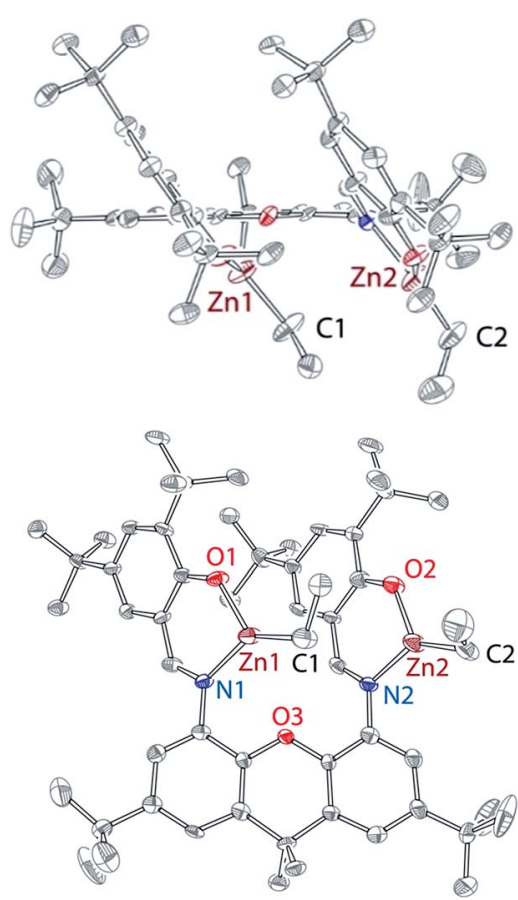

Fig. 7 X-ray structure (50\% ellipsoids) of 5 (top view and side view). H atoms, co-crystallized ether solvent, and an alternative orientation of one of the ethyl groups were omitted for clarity. Selected bond distances ( $\AA$ ) and angles ( ${ }^{\circ}$ ): Zn1 O1 1.910(4), Zn1 C1 1.926(6), Zn1 N1 1.991(4), Zn2 O2 1.900(4), Zn2 C2 1.923(6), Zn1 N2 1.992(4), O1 Zn1 C1 126.8(2), O1 Zn1 N1 93.9(2), C1 Zn1 N1 139.0(2), O2 Zn2 C2 127.4(2), O2 Zn2 N2 94.1(2), C2 Zn2 N2 138.4(2). 
which the zinc centre is 3 -coordinate ${ }^{25}$ Based on our unsuccessful attempts to synthesize a mononuclear analogue (see below), we propose that this structure is stabilized by the dinucleating ligand. A notable feature of the structure is the relatively short distance between $\mathrm{Zn} 2$ and $\mathrm{C} 1$ (methylene bound to $\mathrm{Zn2}$ ), $3.46 \AA$, due to the syn-parallel geometry. One could propose that the $\mathrm{Zn} 2-\mathrm{C} 1$ bond formation, which can be easily achieved by a minimal rotation of the $\mathrm{N} 2 \mathrm{O} 2 \mathrm{Zn} 2$ chelate towards the N1O1Zn1 chelate, can serve as a first step in the proposed transformation of $\mathbf{5}$ into $\mathbf{2}$ and $\mathrm{ZnEt}_{2}$ (Scheme 2).

Treatment of 5 with two equivalents of $\mathrm{BnOH}$ in $\mathrm{C}_{6} \mathrm{D}_{6}$ led to the clean formation of di-benzyloxy complex 6 as indicated by ${ }^{1} \mathrm{H}$ and ${ }^{13} \mathrm{C}$ NMR spectroscopy. The NMR spectrum of $\mathbf{6}$ contains a single and sharp set of dinucleating ligand resonances, consistent with a single isomer in solution. In contrast, benzyloxy resonances appear broadened, which indicates a dynamic process. Such dynamic process, comprising primarily benzyloxy, may involve monomer-dimer equilibrium, in which zincs are bridged by the alkoxide ligand. VT NMR experiments, carried out in the $\mathrm{CD}_{2} \mathrm{Cl}_{2}$ solution of 6 down to $-75^{\circ} \mathrm{C}$, resolved some of the benzyloxy signals. Our repeated attempts to isolate complex 6 by recrystallization from several different solvents $\left(\mathrm{C}_{6} \mathrm{D}_{6}, \mathrm{C}_{7} \mathrm{D}_{8}, \mathrm{CD}_{2} \mathrm{Cl}_{2}\right)$ led to the isolation of yellow crystals of the tetranuclear complex 7 (Fig. 8), that was characterized by X-ray crystallography, ${ }^{1} \mathrm{H}$ NMR spectroscopy, and elemental analysis. Due to the poor solubility of 7 , we were not able to obtain its ${ }^{13} \mathrm{C}$ NMR spectrum. In 7, one of the benzyloxy groups (of 6) has been replaced by the hydroxyl group. The " $\mathrm{Zn}_{2}(\mathrm{~L})(\mathrm{OBn})(\mathrm{OH})$ " fragments then dimerize to form centrosymmetric 7 . We note that (i) 7 exhibits syn geometry of the zinc-benzyloxy units in each complex; (ii) the ${ }^{1} \mathrm{H}$ NMR spectrum of 7 differs significantly from that of $\mathbf{6}$. Whereas hydrolysis of 6 to give 7 can't be ruled out, NMR suggests otherwise as (i) no noticeable amounts of water are detected in $\mathrm{BnOH}$ (anhydrous, 99.8\%); (ii) NMR monitoring of the decomposition of $\mathbf{6}$ demonstrated formation of multiple species exhibiting signals in the olefinic (5-6 ppm) region.

The synthesis of a mononuclear analogue of $\mathbf{5}$ was also attempted (Fig. 9). An iminophenolate ligand $\mathbf{L}^{\prime}$ was synthesized, and reacted with excess of diethyl zinc, in order to obtain the $\mathrm{Zn}\left(\mathbf{L}^{\prime}\right)(\mathrm{Et})$ complex. However, invariably of the amount of diethylzinc used in the reaction (3-6 equivalents), the reaction leads to the formation of two species, none of which possess

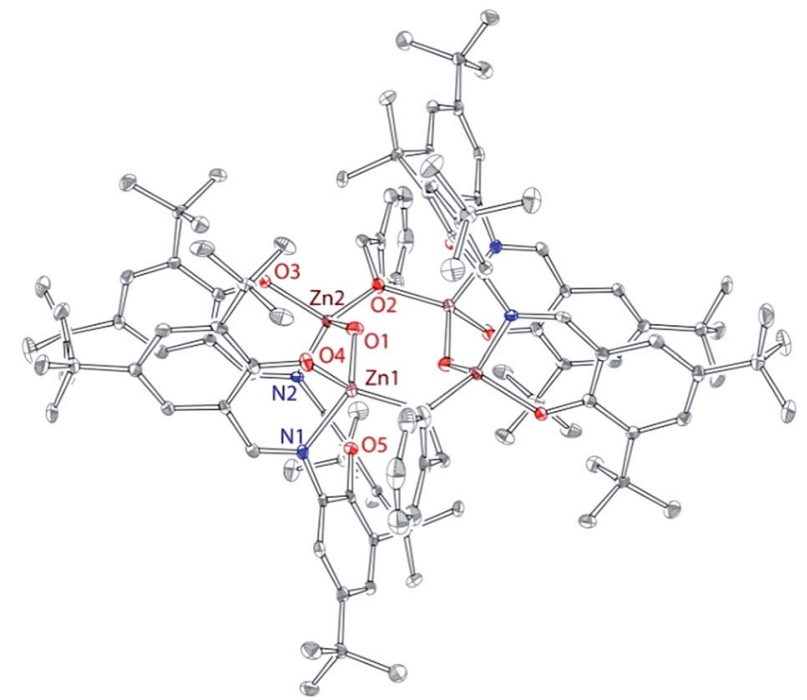

Fig. 8 X-ray structure (50\% ellipsoids) of 7. H atoms, co-crystallized toluene solvent, and an alternative orientation of two of the tert-butyl groups were omitted for clarity. Selected bond distances $(\AA)$ and angles $\left(^{\circ}\right)$ : Zn1 O1 1.943(2), Zn2 O1 1.922(2), Zn1 O2 1.931(2), Zn2 O2 1.954(2), Zn2 O3 1.949(2), Zn1 O4 1.937(2), Zn2 O1 Zn1 131.0(1), Zn2 O2 Zn1 120.0(1).

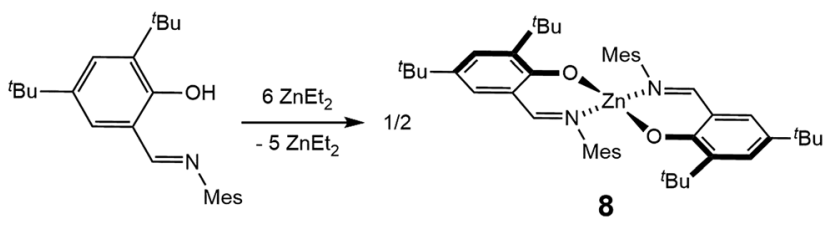

Fig. 9 Reaction of $\mathrm{L}^{\prime}$ with excess $\mathrm{ZnEt}_{2}$ forming the bis(homoleptic) product 8 .

signals attributable to the ethyl group in the ${ }^{1} \mathrm{H}$ NMR spectrum. Recrystallization leads to the isolation of the major product, bis(homoleptic) $\mathrm{Zn}\left(\mathbf{L}^{\prime}\right)_{2}$ complex 8, in $78 \%$ yield, that has been characterized by ${ }^{1} \mathrm{H}$ and ${ }^{13} \mathrm{C}$ NMR spectroscopy, elemental analysis, and X-ray crystallography (see ESI $\dagger$ ). We note the scarcity of tri-coordinate iminophenolate-zinc-ethyl complexes in the literature. While in some cases such complexes were synthesized, it was shown or hypothesized that they adopt phenoxide-bridged dimeric/polymeric structures in the solid
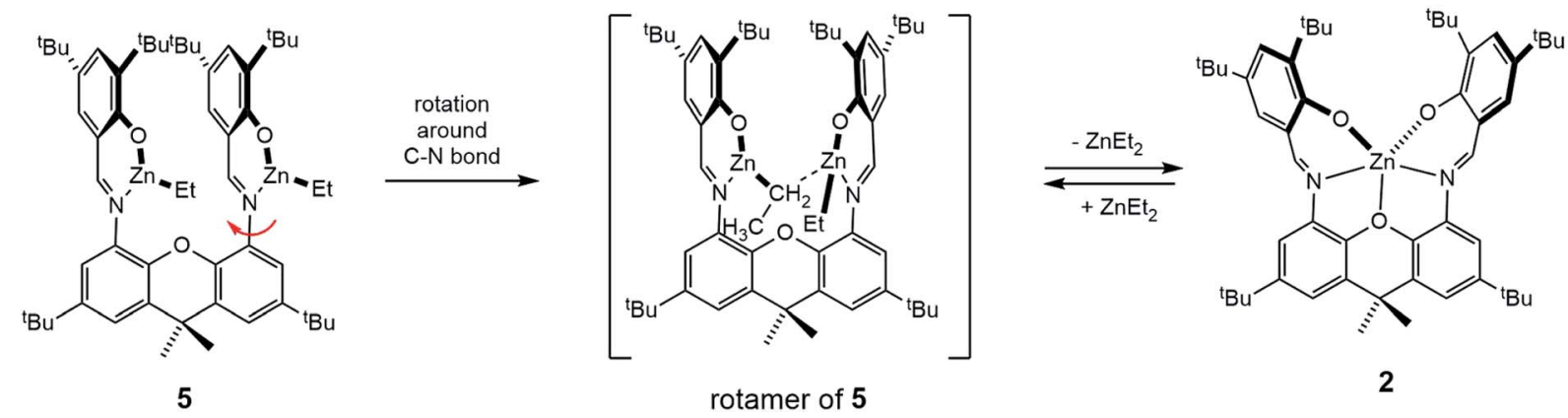

Scheme 2 Possible mechanism for the formation of complex 2 from complex 5 . 
Table 1 Polymerization of rac-LA by $6^{a, f}$

\begin{tabular}{|c|c|c|c|c|c|c|c|c|}
\hline & {$[\mathrm{I}] /[\mathrm{BnOH}] /[\mathrm{LA}]$} & Temp $\left({ }^{\circ} \mathrm{C}\right)$ & Time (h) & Conv $^{b}$ & $M_{\mathrm{n}(\text { calc })^{c}}$ & $M_{\mathrm{n}}^{d}$ & PDI & $P_{\mathrm{r}}^{e}$ \\
\hline 1 & $1 / 2 / 600$ & 25 & 16 & 0.60 & 25900 & 15420 & 1.18 & 0.66 \\
\hline 2 & $1 / 2 / 600$ & 25 & 24 & 0.86 & 37200 & 23430 & 1.23 & 0.67 \\
\hline 4 & $1 / 10 / 1000$ & 25 & 24 & 0.69 & 9900 & 5300 & 1.19 & 0.65 \\
\hline 5 & $1 / 2 / 600$ & 70 & 1 & 0.88 & 38000 & 21700 & 1.43 & 0.58 \\
\hline 6 & $1 / 2 / 600$ & 70 & 2 & 0.98 & 42300 & 24000 & 1.67 & 0.54 \\
\hline
\end{tabular}

${ }^{a}$ Polymerizations performed in $\mathrm{CH}_{2} \mathrm{Cl}_{2}$ (entries 1-4, $5 \mathrm{~mL}$ ) or toluene (entries 5 and 6, $5 \mathrm{~mL}$ ) employing $5 \mu$ mol of catalyst. ${ }^{b}$ Determined by ${ }^{1} \mathrm{H}$ NMR spectroscopy $(500 \mathrm{MHz}) .{ }^{c}$ Calculated from $[\mathrm{LA}] /[\mathrm{BnOH}]$ ratio multiplied by monomer conversion. ${ }^{d}$ Determined by GPC analysis calibrated with polystyrene standards and multiplied by a correction factor of 0.58 . Values are given in $\mathrm{g} \mathrm{mol}^{-1} .{ }^{e}$ Determined from the methine region of the HD ${ }^{1} \mathrm{H}$ NMR spectrum. ${ }^{f} \mathbf{6}$ was formed in situ, by treating 5 with $\mathrm{BnOH}$.

state. ${ }^{25}$ We also note that in a related study on the synthesis of iminophenolate zinc pre-catalysts for lactide polymerization, bis(homoleptic) complexes were obtained for any ortho-phenolate substituents smaller than cumyl. ${ }^{25 c}$ Thus, while the bimetallic cooperativity of $\mathbf{L}$ in polymerization could not be directly assessed by a comparison with a mononuclear analogue, $\mathbf{L}$ enables bimetallic cooperativity in the formation of the desired diethyl complex, whose mononuclear analogue does not form.

\section{Lactide polymerization}

We investigated the catalytic activity of $\mathrm{Zn}_{2}(\mathbf{L})(\mathrm{OBn})_{2}$, formed in $s i t u$, in the ring-opening polymerization (ROP) of rac-LA. Polymerization attempts were performed in dichloromethane at room temperature by adding benzyl alcohol to 5 followed by racLA (see Table 1). Under these conditions, the polymerization of 600 equivalents of $r a c$-lactide reached high conversion of $86 \%$ after $24 \mathrm{~h}$, exhibiting comparable activity to other dinuclear zinc catalysts. ${ }^{9 b, 16}$ Gel-permeation analysis (GPC) of the PLA samples obtained revealed narrow molecular-weight distribution (PDI $\leq$ 1.23), signifying a well-controlled polymerization reaction. Increasing the benzyl alcohol ratio to beyond a single equivalent per zinc centre led to "immortal polymerization" ${ }^{27}$ yielding PLA samples with narrow MWD and expected MW according to initiator/benzyl alcohol/monomer ratios. Homo-decoupled ${ }^{1} \mathrm{H}$ analysis indicated that 6 led to heterotactically-inclined PLA $\left(P_{\mathrm{r}}=0.67\right)$, as reported with other dinuclear zinc complexes. ${ }^{7 g, 16}$

Attempting to attain higher activities, polymerization runs were performed at $70{ }^{\circ} \mathrm{C}$ in toluene. High conversion of $88 \%$ was obtained only after 1 hour yielding PLA with reduced heterotacticity $\left(P_{\mathrm{r}}=0.58\right)$ and higher PDI values. Extending the reaction time to 2 hours led to almost full conversion, however, heterotacticity and dispersity were further decreased. The deterioration of the sample qualities at high conversion might be a result of trans-esterification side reactions, which increase at elevated temperatures.

\section{Conclusions}

This study pursued synthesis of new di-zinc complexes, stabilized by a xanthene-bridged bis(iminophenolate) ligand, which could serve as a lactide polymerization catalyst. $\mathbf{L}$ demonstrated rich coordination chemistry with various zinc precursors, leading to mononuclear (with zinc alkoxide), syn-dinuclear (with diethyl zinc), or anti-dinuclear (with zinc chloride) complexes. Syn-dinuclear complex $\mathrm{Zn}_{2}(\mathbf{L})\left(\mathrm{Et}_{2}\right)$, obtained via a protonolysis reaction of $\mathbf{L}$ with excess diethylzinc, decomposes in solution into a mononuclear complex $\mathrm{Zn}(\mathbf{L})$, along with $\mathrm{ZnEt}_{2}$; this reaction can then be reversed by the addition of excess $\mathrm{ZnEt}_{2}$. Interestingly, no mononuclear analogue of $\mathrm{Zn}_{2}(\mathbf{L})\left(\mathrm{Et}_{2}\right)$ could be isolated as the protonolysis reaction of mononucleating iminophenol bearing comparable substituents $\left(\mathbf{L}^{\prime}\right)$ with diethylzinc leads instead to the bis(homoleptic) complex $\operatorname{Zn}\left(\mathbf{L}^{\prime}\right)_{2}$. Thus, while we could not directly assess cooperative reactivity in catalysis, our dinucleating ligand enables "cooperative synthesis" of two nearby zinc-iminophenolate-ethyl sites, possibly by virtue of sterics. $\mathrm{Zn}_{2}(\mathbf{L})\left(\mathrm{Et}_{2}\right)$ underwent clean reaction with benzyl alcohol to form benzyloxy species $\mathrm{Zn}_{2}(\mathbf{L})(\mathrm{OBn})_{2}$. $\mathrm{Zn}_{2}(\mathbf{L})(\mathrm{OBn})_{2}$ served as an efficient lactide polymerization catalyst, forming heterotactically-inclined PLA. Room-temperature polymerization experiments, carried out in dichloromethane, led to the formation of polymers of relatively narrow MWD, suggesting well-controlled polymerization under these conditions. Polymerization experiments in toluene, carried out at $70{ }^{\circ} \mathrm{C}$, demonstrated higher activity, but led to higher PDI values, and diminished heterotacticity. Our future studies will focus on the reactivity of this and related systems in polymerization of epoxides and copolymerization of epoxides with $\mathrm{CO}_{2}$.

\section{Experimental}

\section{General}

All reactions involving air-sensitive materials were carried out in a nitrogen-filled glovebox. 2,7-di-tert-butyl-9,9-dimethyl-4,5diaminoxanthene, di-tert-butyl-phenylmethoxide (LiOR) and di-tert-butyl-phenylmethanol (HOR) were synthesized according to previously published procedures. ${ }^{22}$ Synthesis of $\mathbf{L}^{\prime}$ has been previously reported as well. ${ }^{26}$ Di-tert-butylsalicylaldehyde, zinc chloride and diethyl zinc (1.0 M solution in hexanes) were purchased from Sigma and used as received. Rac-lactide was purchased from Sigma, and was purified by crystallization from dry toluene and sublimation. All non-deuterated solvents were purchased from Aldrich and were of HPLC grade. The nondeuterated solvents were purified using an MBraun solvent purification system. Benzene- $\mathrm{d}_{6}$, toluene- $\mathrm{d}_{8}$, dichloromethane- 
$\mathrm{d}_{2}$, and chloroform- $\mathrm{d}_{1}$ were purchased from Cambridge Isotope Laboratories. All solvents were stored over $3 \AA$ molecular sieves. Compounds were generally characterized by ${ }^{1} \mathrm{H}$ and ${ }^{13} \mathrm{C} \mathrm{NMR}$, $\mathrm{X}$-ray crystallography, and elemental analysis. NMR spectra of the ligands and metal complexes were recorded at the Lumigen Instrument Centre (Wayne State University) on an Agilent 400 $\mathrm{MHz}$ Spectrometer in $\mathrm{C}_{6} \mathrm{D}_{6}, \mathrm{C}_{7} \mathrm{D}_{8}$, or $\mathrm{CD}_{2} \mathrm{Cl}_{2}$ at room temperature. NMR spectra of PLA samples were recorded on Bruker Advance III $500 \mathrm{MHz}$ spectrometer in $\mathrm{CDCl}_{3}$ at room temperature. Chemical shifts and coupling constants $(J)$ were reported in parts per million $(\delta)$ and Hertz respectively. Detailed assignments of the signals in ${ }^{1} \mathrm{H}$ NMR are given in the ESI. $\dagger$ X-ray structures were collected using Bruker Apex2 at the Lumigen Instrument Centre (Wayne State University). Full details on data collection, structure solution and refinement are given in the ESI. $\dagger$ Elemental analysis was performed under ambient air-free conditions by Midwest Microlab LLC. The molecular weights $\left(M_{\mathrm{n}}\right.$ and $\left.M_{\mathrm{w}}\right)$ and the molecular mass distributions $\left(M_{\mathrm{w}} / M_{\mathrm{n}}\right)$ of the PLA samples were measured by gel permeation chromatography (GPC) at $30{ }^{\circ} \mathrm{C}$, using THF as solvent, a flow rate of eluent of $1 \mathrm{~mL} \min ^{-1}$, and narrow $\mathrm{MW}$ polystyrene standards as reference. The measurements were performed on a Jasco system equipped with an RI 1530 detector. A correction factor of 0.58 was employed for the molecular weight of PLA relative to polystyrene.

\section{Synthesis and characterization of $L$ and compounds 1-8}

Preparation of L. A $15 \mathrm{~mL}$ solution of 3,5-di-tert-butyl-2hydroxybenzaldehyde $(1.33 \mathrm{~g}, 5.68 \mathrm{mmol}, 2.0$ equiv.) in methanol was added dropwise to a stirring $15 \mathrm{~mL}$ solution of 2,7di-tert-butyl-9,9-dimethyl-9H-xanthene-4,5-diamine $(1.00 \mathrm{~g}$, $2.84 \mathrm{mmol}, 1.0$ equiv.) in methanol. The reaction mixture was heated to reflux and stirred for 24 hours. The reaction mixture was cooled to room temperature and the volatiles were removed in vacuo. The resulting solid was dissolved in a minimum amount of benzene and layered with excess methanol. Overnight recrystallization at room temperature afforded $\mathbf{L}$ as yellow crystals (1.69 g, $2.15 \mathrm{mmol}, 76 \%) .{ }^{1} \mathrm{H}$ NMR $\left(\mathrm{C}_{6} \mathrm{D}_{6}, 400 \mathrm{MHz}\right)$ $\delta 14.45(\mathrm{~s}, 2 \mathrm{H}), 8.58(\mathrm{~s}, 2 \mathrm{H}), 7.51\left(\mathrm{~d},{ }^{4} J_{\mathrm{HH}}=2.4 \mathrm{~Hz}, 2 \mathrm{H}\right), 7.37(\mathrm{~d}$, $\left.{ }^{4} J_{\mathrm{HH}}=2.0 \mathrm{~Hz}, 2 \mathrm{H}\right), 7.00\left(\mathrm{~d},{ }^{4} J_{\mathrm{HH}}=2.4 \mathrm{~Hz}, 2 \mathrm{H}\right), 6.96\left(\mathrm{~d},{ }^{4} J_{\mathrm{HH}}=\right.$ $2.0 \mathrm{~Hz}, 2 \mathrm{H}), 1.67$ (s, 6H), 1.45 (s, 18H), $1.26(\mathrm{~s}, 36 \mathrm{H}) .{ }^{13} \mathrm{C}\left\{{ }^{1} \mathrm{H}\right\}$ NMR $\left(\mathrm{C}_{6} \mathrm{D}_{6}, 100 \mathrm{MHz}\right) \delta 165.65,160.05,146.51,142.21,140.21$, $137.65,137.15,130.82$, 128.92, 127.40, 120.80, 119.68, 118.36, $35.65,35.39,35.00,34.54,33.30,32.07,31.93,29.97$. Anal. calcd for $\mathrm{C}_{53} \mathrm{H}_{72} \mathrm{~N}_{2} \mathrm{O}_{3}$ : C, 81.08; H, 9.24; N, 3.61. Found: C, 81.12; H, 8.99; N, 3.61.

Preparation of $\mathrm{Zn}(\mathrm{Cl})\left(\mu_{2}-\mathrm{OR}\right)_{2} \mathrm{Li}(\mathrm{THF})$ (1). A $2 \mathrm{~mL}$ solution of LiOR (66 mg, $0.29 \mathrm{mmol}, 2.0$ equiv.) in THF and a $2 \mathrm{~mL}$ solution of $\mathrm{ZnCl}_{2}$ (20 mg, $0.15 \mathrm{mmol}, 1$ equiv.) in THF were prepared and cooled to $-33{ }^{\circ} \mathrm{C}$. The chilled solution of LiOR was then added dropwise to a stirring solution of the chilled $\mathrm{ZnCl}_{2}$. The reaction mixture was stirred for 1 hour, upon which the volatiles were removed in vacuo. The resulting solid was dissolved in $5 \mathrm{~mL}$ of hexane, filtered, and the volatiles removed in vacuo to afford 1 as a white crystalline powder (68 $\mathrm{mg}, 0.11 \mathrm{mmol}, 75 \%)$. X-ray quality crystals were obtained from a saturated hexane solution of $1 \mathrm{kept}$ at $-33{ }^{\circ} \mathrm{C} .{ }^{1} \mathrm{H}$ NMR $\left(\mathrm{C}_{6} \mathrm{D}_{6}, 400 \mathrm{MHz}\right) \delta 8.02(\mathrm{~d}$, $\left.{ }^{3} J_{\mathrm{HH}}=7.8 \mathrm{~Hz}, 2 \mathrm{H}\right), 7.68\left(\mathrm{~d},{ }^{3} J_{\mathrm{HH}}=7.8 \mathrm{~Hz}, 2 \mathrm{H}\right), 7.28\left(\mathrm{t},{ }^{3} J_{\mathrm{HH}}=\right.$ $7.8 \mathrm{~Hz}, 2 \mathrm{H}), 7.07$ (m, 4H), 2.89 (m, 4H, THF), 1.33 (s, 36H), 1.01 $(\mathrm{m}, 4 \mathrm{H}, T H F) .{ }^{13} \mathrm{C}\left\{{ }^{1} \mathrm{H}\right\} \mathrm{NMR}\left(\mathrm{C}_{6} \mathrm{D}_{6}, 100 \mathrm{MHz}\right) \delta 150.90,130.48$, 127.15, 126.12, 125.97, 85.81, 68.13, 42.12, 31.24, 24.92.

Preparation of $\mathbf{Z n}(\mathrm{L}) \cdot(\mathbf{R O H})(2 \cdot \mathbf{H O R})$. Method A: A $2 \mathrm{~mL}$ solution of $\mathrm{TlPF}_{6}(20 \mathrm{mg}, 0.057 \mathrm{mmol}, 2.0$ equiv.) in THF, a $2 \mathrm{~mL}$ solution of 1 ( $35 \mathrm{mg}, 0.057 \mathrm{mmol}, 2.0$ equiv.) in THF, and a $2 \mathrm{~mL}$ solution of $\mathbf{L}$ ( $23 \mathrm{mg}, 0.029 \mathrm{mmol}, 1$ equiv.) were prepared and cooled to $-33^{\circ} \mathrm{C}$. The chilled solution of 1 was then added dropwise to a stirring solution of the chilled $\mathrm{TlPF}_{6}$, producing a cloudy white solution. The reaction mixture was stirred for $1 \mathrm{~h}$, filtered, and the volatiles were removed in vacuo. The resulting solid was dissolved in $5 \mathrm{~mL}$ of hexane and filtered again. The chilled solution of $\mathbf{L}$ was then added dropwise to a stirring solution of the hexane filtrate, producing an orange solution. The reaction mixture was stirred for 1 hour, upon which the volatiles were removed in vacuo. Overnight recrystallization at $-33{ }^{\circ} \mathrm{C}$ from a saturated ether solution afforded $2 \cdot$ HOR as orange crystals (20 mg, $0.019 \mathrm{mmol}, 65 \%$ ). Method B: A $2 \mathrm{~mL}$ solution of 1 ( $34 \mathrm{mg}, 0.054 \mathrm{mmol}, 2.0$ equiv.) in THF and a $2 \mathrm{~mL}$ solution of $\mathbf{L}(21 \mathrm{mg}, 0.027 \mathrm{mmol}, 1$ equiv.) were prepared and cooled to $-33{ }^{\circ} \mathrm{C}$. The chilled solution of $\mathbf{L}$ was then added dropwise to a stirring solution of the chilled $\mathbf{1}$, producing an orange solution. The reaction mixture was stirred for $1 \mathrm{~h}$, upon which the volatiles were removed in vacuo. The resulting solid was dissolved in $5 \mathrm{~mL}$ of hexane, filtered, and the volatiles were removed in vacuo. Overnight recrystallization at $-33{ }^{\circ} \mathrm{C}$ from a saturated ether solution afforded $2 \cdot \mathrm{HOR}$ as orange crystals (14 mg, $0.013 \mathrm{mmol}, 49 \%) .{ }^{1} \mathrm{H}$ NMR $\left(\mathrm{C}_{6} \mathrm{D}_{6}, 400\right.$ MHz) $\delta 8.55(\mathrm{~s}, 2 \mathrm{H}), 7.79\left(\mathrm{~d},{ }^{3} J_{\mathrm{HH}}=8.3 \mathrm{~Hz}, 1 \mathrm{H}\right), 7.60\left(\mathrm{~d},{ }^{4} J_{\mathrm{HH}}=\right.$ $2.0 \mathrm{~Hz}, 2 \mathrm{H}), 7.46(\mathrm{~m}, 1 \mathrm{H}), 7.25(\mathrm{~m}, 1 \mathrm{H}), 7.18(\mathrm{~s}, 2 \mathrm{H}), 7.10(\mathrm{~m}$, $6 \mathrm{H}), 1.56(\mathrm{~s}, 1 \mathrm{H}, \mathrm{R}-\mathrm{OH}), 1.51(\mathrm{~s}, 18 \mathrm{H}), 1.42(\mathrm{~s}, 6 \mathrm{H}), 1.40(\mathrm{~s}, 18 \mathrm{H})$, $1.23(\mathrm{~s}, 18 \mathrm{H}), 1.02(\mathrm{~s}, 18 \mathrm{H}) ;{ }^{13} \mathrm{C}\left\{{ }^{1} \mathrm{H}\right\}$ NMR $\left(\mathrm{C}_{6} \mathrm{D}_{6}, 100 \mathrm{MHz}\right)$ $\delta 172.65,165.91,147.78,142.88,135.50,133.63,130.90,128.66$, $126.28,126.09,119.81,118.26,111.33,41.77,36.77,36.01$, $35.16,34.15,31.70,31.63,29.84,29.74,28.17$.

Preparation of $\mathbf{L i}_{3}(\mathbf{L})\left(\mu^{3}-\mathbf{O}^{t} \mathbf{B u}\right)(\mathbf{T H F})_{n}$ (3). Stirred solution of $\mathbf{L}$ (94 $\mathrm{mg}, 0.120 \mathrm{mmol}$ ) in $2 \mathrm{~mL}$ of ether was treated with excess $\mathrm{LiO}^{t} \mathrm{Bu}(\sim 1 \mathrm{M}$ solution in THF), yielding bright yellow solution. The reaction was stirred for $1 \mathrm{~h}$, after which volatiles were removed in vacuo. The resulting yellow solid was dissolved in a mixture of hexane and ether $(2: 1 \mathrm{~mL})$, filtered through celite, and the solution was concentrated to approximately $2 \mathrm{~mL}$ total volume. Recrystallization at $-33{ }^{\circ} \mathrm{C}$ yields $\mathrm{Li}_{3}(\mathbf{L})\left(\mu^{3}-\mathrm{O}^{t} \mathrm{Bu}\right)(\mathrm{THF})$ as yellow microcrystalline solid (100 mg, $0.105 \mathrm{mmol}, 88 \%$ yield). The compound was characterized by ${ }^{1} \mathrm{H}$ and ${ }^{13} \mathrm{C}$ NMR spectroscopy, elemental analysis, and X-ray crystallography. ${ }^{1} \mathrm{H}$ NMR $\left(\mathrm{C}_{6} \mathrm{D}_{6}, 400 \mathrm{MHz}\right) \delta 8.50(\mathrm{~s}, 2 \mathrm{H}), 7.64\left(\mathrm{~d},{ }^{4} J_{\mathrm{HH}}=2 \mathrm{~Hz}, 2 \mathrm{H}\right)$, $7.33\left(\mathrm{~d},{ }^{4} J_{\mathrm{HH}}=2 \mathrm{~Hz}, 2 \mathrm{H}\right), 7.15\left(\mathrm{~d},{ }^{4} J_{\mathrm{HH}}=2 \mathrm{~Hz}, 2 \mathrm{H}\right), 7.05(\mathrm{~d}$, $\left.{ }^{4} J_{\mathrm{HH}}=2 \mathrm{~Hz}, 2 \mathrm{H}\right), 3.31(\mathrm{~m}, 8 \mathrm{H}, \mathrm{THF}) 1.76(\mathrm{~s}, 3 \mathrm{H}, \mathrm{Me}), 1.64(\mathrm{~s}$, $18 \mathrm{H}), 1.57$ (s, 3H, Me), 1.37 (s, 9H), 1.32 (s, 18H), $1.26(\mathrm{~m}, 8 \mathrm{H}$, THF), 1.21 (s, 18H). ${ }^{13} \mathrm{C}\left\{{ }^{1} \mathrm{H}\right\}$ NMR $\left(\mathrm{C}_{6} \mathrm{D}_{6}, 100 \mathrm{MHz}\right) \delta 170.02$, 168.20, 147.16, 143.32, 141.20, 140.11, 134.17, 131.70, 131.37, 129.43, 128.35, 123.13, 118.12, 68.14, 35.80, 35.52, 35.49, 35.30, $34.99,34.87,33.98,31.80,31.67,30.60,25.75,25.66,25.38$. Anal. 
calcd for $\mathrm{C}_{57} \mathrm{H}_{76} \mathrm{Li}_{2} \mathrm{~N}_{2} \mathrm{O}_{4} \mathrm{Zn}_{2} \times \mathrm{C}_{4} \mathrm{H}_{8} \mathrm{O}: \mathrm{C}, 77.27 ; \mathrm{H}, 9.14 ; \mathrm{N}, 2.95$. Found: C, 76.71; H, 9.09; N, 2.95.

Preparation of $\mathrm{Zn}_{2} \mathbf{L i}_{2}(\mathrm{~L})\left(\mathrm{Cl}_{4}\right)\left(\mathrm{OEt}_{2}\right)_{4}$ (4). A $3 \mathrm{~mL}$ solution of $\mathrm{Li}_{3}(\mathbf{L})\left(\mu^{3}-\mathrm{O}^{t} \mathrm{Bu}\right)(\mathrm{THF})(85 \mathrm{mg}, 0.11 \mathrm{mmol}, 1.0$ equiv.) in ether was added to a stirring $2 \mathrm{~mL}$ solution of $\mathrm{ZnCl}_{2}(30 \mathrm{mg}, 0.21 \mathrm{mmol}$, 2.0 equiv.) in ether, producing a deep yellow solution. The reaction mixture was stirred for 1 hour, filtered, and volatiles removed in vacuo. The resulting yellow solid was dissolved in a mixture of hexane and ether $(4: 1 \mathrm{~mL})$ and concentrated in vacuo. Overnight recrystallization at $-33{ }^{\circ} \mathrm{C}$ afforded X-ray quality crystals of 4 as yellow blocks $(67 \mathrm{mg}, 0.046 \mathrm{mmol}$, $43 \%) .{ }^{1} \mathrm{H}$ NMR $\left(\mathrm{CD}_{2} \mathrm{Cl}_{2}, 400 \mathrm{MHz}\right) \delta 8.86$ (br s, $\left.2 \mathrm{H}\right), 8.48$ (br s, $2 \mathrm{H}), 7.55-6.90(\mathrm{~m}, 6 \mathrm{H}), 3.45\left(\mathrm{q},{ }^{3} J_{\mathrm{HH}}=8 \mathrm{~Hz}, 16 \mathrm{H}\right), 1.73(\mathrm{~s}, 6 \mathrm{H})$, $1.39(\mathrm{~s}, 18 \mathrm{H}), 1.61(\mathrm{~s}, 3 \mathrm{H}), 1.26(\mathrm{br} \mathrm{s}, 36 \mathrm{H}), 1.16\left(\mathrm{t},{ }^{3} J_{\mathrm{HH}}=8 \mathrm{~Hz}\right.$, $24 \mathrm{H})$. Anal. Cald for $\mathrm{C}_{69} \mathrm{H}_{110} \mathrm{Cl}_{4} \mathrm{Li}_{2} \mathrm{~N}_{2} \mathrm{O}_{7} \mathrm{Zn}_{2} \times \mathrm{C}_{6} \mathrm{H}_{14}: \mathrm{C}, 62.03$; $\mathrm{H}, 8.61$; N, 1.93. Found: C, 61.76; H, 8.25; N, 1.58.

Preparation of $\mathbf{Z n}_{2}(\mathbf{L})(\mathbf{E t})_{\mathbf{2}}$ (5). A $3 \mathrm{~mL}$ solution of $\mathbf{L}(34 \mathrm{mg}$, $0.043 \mathrm{mmol}, 1.0$ equiv.) in ether and a $2 \mathrm{~mL}$ solution of diethyl zinc ( $0.28 \mathrm{mmol}, 6.5$ equiv.) in hexane were prepared and cooled to $-33{ }^{\circ} \mathrm{C}$. The solution of chilled $\mathbf{L}$ was then added dropwise to a stirring solution of the chilled diethyl zinc, producing a neon yellow solution. The reaction mixture was stirred for 1 hour, upon which the volatiles were removed in vacuo to afford the pure product as a neon yellow solid (46 mg, $0.041 \mathrm{mmol}, 95 \%$ ). $\mathrm{X}$-ray quality crystals were obtained from a saturated ether solution of $\mathbf{5}$ at $-33{ }^{\circ} \mathrm{C}$; the complex co-crystalized with two ether molecules per one molecule of $5 .{ }^{1} \mathrm{H} \mathrm{NMR}\left(\mathrm{C}_{6} \mathrm{D}_{6}, 400 \mathrm{MHz}\right.$, $\sim 60 \mathrm{mM}) \delta 8.20(\mathrm{~s}, 2 \mathrm{H}), 7.63(\mathrm{~s}, 2 \mathrm{H}), 7.36(\mathrm{~s}, 2 \mathrm{H}), 6.85(\mathrm{~s}, 2 \mathrm{H})$, 6.79 (br s, 2H), 1.62 (s, 18H), ca. 1.4 (br s, 6H, Xanthene-Me), ca. 1.4 (br s, 6H, Zn- $\mathrm{CH}_{2} \mathrm{CH}_{3}$ ), 1.24 (s, 36H), 0.64 (br s, 4H, $\left.\mathrm{Z}-\mathrm{CH}_{2} \mathrm{CH}_{4}\right) .{ }^{13} \mathrm{C}$ NMR $\left(\mathrm{C}_{6} \mathrm{D}_{6}, 100 \mathrm{MHz}\right) \delta 171.88,170.40,147.18$, 142.27, 140.62, 138.62, 136.61, 132.41, 130.77, 130.01, 121.36, 120.78, 118.29, 66.25, 36.18, 35.40, 35.08, 34.36, 32.31, 31.92, 31.84, 30.36, 23.40, 14.70. Anal. calcd for $\mathrm{C}_{57} \mathrm{H}_{80} \mathrm{~N}_{2} \mathrm{O}_{3} \mathrm{Zn}_{2} \times$ $2 \mathrm{C}_{4} \mathrm{H}_{10} \mathrm{O}$ : C, 69.69; H, 9.00; N, 2.50. Found: C, 69.25; H, 8.57; N, 1.98 .

Preparation of $\mathbf{Z n}_{2}(\mathbf{L})(\mathbf{O B n})_{2}$ (6). Method A: A $0.5 \mathrm{~mL}$ solution of $\mathrm{BnOH}$ ( $5 \mathrm{mg}, 0.042 \mathrm{mmol}, 2$ equiv.) in $\mathrm{C}_{6} \mathrm{D}_{6}$ was added dropwise to a stirring solution of $5(20 \mathrm{mg}, 0.021 \mathrm{mmol}, 1$ equiv.) in $0.5 \mathrm{~mL} \mathrm{C}_{6} \mathrm{D}_{6}$, producing a yellowish-orange solution. The reaction mixture was stirred for 30 minutes and NMR was obtained. Absence of NMR signals corresponding to $\mathbf{5}$ and $\mathrm{BnOH}$ implies complete quantitative conversion to $6 .{ }^{1} \mathrm{H} \mathrm{NMR}$ $\left(\mathrm{C}_{6} \mathrm{D}_{6}, 400 \mathrm{MHz}\right) \delta 8.55(\mathrm{~s}, 2 \mathrm{H}), 7.60\left(\mathrm{~d},{ }^{4} J_{\mathrm{HH}}=2.4 \mathrm{~Hz}, 2 \mathrm{H}\right), 7.20-$ 7.05 (br, $10 \mathrm{H}$, aromatic protons on $\mathrm{BnO}), 7.18\left(\mathrm{~d},{ }^{4} J_{\mathrm{HH}}=2.4 \mathrm{~Hz}\right.$, $2 \mathrm{H}), 7.11\left(\mathrm{~d},{ }^{4} J_{\mathrm{HH}}=2.4 \mathrm{~Hz}, 2 \mathrm{H}\right), 7.10\left(\mathrm{~d},{ }^{4} J_{\mathrm{HH}}=2.4 \mathrm{~Hz}, 2 \mathrm{H}\right), 4.31$ (br s, $4 \mathrm{H}$, methylene protons on $\mathrm{BnO}), 1.51(\mathrm{~s}, 18 \mathrm{H}), 1.42(\mathrm{~s}, 6 \mathrm{H})$, $1.41(\mathrm{~s}, 18 \mathrm{H}), 1.23(\mathrm{~s}, 18 \mathrm{H}) .{ }^{13} \mathrm{C} \mathrm{NMR}\left(\mathrm{C}_{6} \mathrm{D}_{6}, 100 \mathrm{MHz}\right) \delta 172.61$, $165.91,147.79,142.87,135.51,133.63,130.89,128.86,119.83$, 118.26, 111.33, 36.78, 36.01, 35.16, 34.15, 31.70, 31.63, 29.74, 28.17. Method B: Same as Method A, substituting $\mathrm{C}_{7} \mathrm{D}_{8}$ (toluene$\mathrm{d}_{8}$ ) for $\mathrm{C}_{6} \mathrm{D}_{6}$. Absence of NMR signals corresponding to 5 and $\mathrm{BnOH}$ implies complete quantitative conversion to $6 .{ }^{1} \mathrm{H} \mathrm{NMR}$ $\left(\mathrm{C}_{7} \mathrm{D}_{8}, 400 \mathrm{MHz}\right) \delta 8.50(\mathrm{~s}, 2 \mathrm{H}), 7.56\left(\mathrm{~d},{ }^{4} \mathrm{~J}_{\mathrm{HH}}=2.4 \mathrm{~Hz}, 2 \mathrm{H}\right), 7.23-$ 7.05 (br, $10 \mathrm{H}$, aromatic protons on $\mathrm{BnO}), 7.21\left(\mathrm{~d},{ }^{4} J_{\mathrm{HH}}=2.4 \mathrm{~Hz}\right.$, $2 \mathrm{H}), 7.14\left(\mathrm{~d},{ }^{4} J_{\mathrm{HH}}=2.4 \mathrm{~Hz}, 2 \mathrm{H}\right), 7.08\left(\mathrm{~d},{ }^{4} J_{\mathrm{HH}}=2.4 \mathrm{~Hz}, 2 \mathrm{H}\right), 4.72$ (br s, 2H, methylene protons on $\mathrm{BnO}$ ), 4.30 (br s, $2 \mathrm{H}$, methylene protons on $\mathrm{BnO}), 1.48(\mathrm{~s}, 6 \mathrm{H}), 1.46(\mathrm{~s}, 18 \mathrm{H}), 1.41(\mathrm{~s}, 18 \mathrm{H}), 1.26(\mathrm{~s}$, $18 \mathrm{H}) .{ }^{13} \mathrm{C}$ NMR $\left(\mathrm{C}_{7} \mathrm{D}_{8}, 100 \mathrm{MHz}\right) \delta 172.60,165.85,147.72$, 142.98, 142.78, 135.60, 135.32, 133.76, 130.80, 128.73, 119.70, 118.19, 111.26, 36.85, 35.93, 35.14, 34.10, 31.62, 31.55, 29.69, 27.99. Method $C$ : Same as Method A, substituting $\mathrm{CD}_{2} \mathrm{Cl}_{2}$ for $\mathrm{C}_{6} \mathrm{D}_{6}$. Absence of NMR signals corresponding to 5 and $\mathrm{BnOH}$ implies complete quantitative conversion to 6. ${ }^{1} \mathrm{H} \mathrm{NMR}\left(\mathrm{CD}_{2} \mathrm{Cl}_{2}\right.$, $400 \mathrm{MHz}) \delta 8.86(\mathrm{~s}, 2 \mathrm{H}), 7.52\left(\mathrm{~d},{ }^{4} J_{\mathrm{HH}}=2.4 \mathrm{~Hz}, 2 \mathrm{H}\right), 7.36\left(\mathrm{~d},{ }^{4} J_{\mathrm{HH}}\right.$ $=2.4 \mathrm{~Hz}, 2 \mathrm{H}), 7.35(\mathrm{br}, 10 \mathrm{H}$, aromatic protons on $\mathrm{BnO}), 7.26$ $\left(\mathrm{d},{ }^{4} J_{\mathrm{HH}}=2.4 \mathrm{~Hz}, 2 \mathrm{H}\right), 7.10\left(\mathrm{~d},{ }^{4} J_{\mathrm{HH}}=2.4 \mathrm{~Hz}, 2 \mathrm{H}\right), 4.76(\mathrm{br} \mathrm{s}, 2 \mathrm{H}$, methylene protons on $\mathrm{BnO}$ ), 4.67 (br s, $2 \mathrm{H}$, methylene protons on $\mathrm{BnO}), 1.71(\mathrm{~s}, 6 \mathrm{H}), 1.40(\mathrm{~s}, 18 \mathrm{H}), 1.29(\mathrm{~s}, 18 \mathrm{H}), 1.02(\mathrm{~s}, 18 \mathrm{H})$; ${ }^{13} \mathrm{C}$ NMR $\left(\mathrm{CD}_{2} \mathrm{Cl}_{2}, 100 \mathrm{MHz}\right) \delta 171.75,166.09,148.72,143.44$, 142.37 , 135.97, 135.43, 134.46, 131.03, 128.68, 119.81, 119.31, 112.00, 37.49, 35.72, 34.31, 31.93, 31.56, 29.37, 28.31.

Preparation of $\mathbf{Z n}_{4}(\mathrm{~L})_{2}(\mathrm{OBn})_{2}(\mathrm{OH})_{2}$ (7). Slow evaporation of $\mathrm{Zn}_{2}(\mathbf{L})(\mathrm{OBn})_{2}(23 \mathrm{mg}, 0.021 \mathrm{mmol})$ in concentrated $\mathrm{CD}_{2} \mathrm{Cl}_{2}$, $\mathrm{C}_{6} \mathrm{D}_{6}$, or $\mathrm{C}_{7} \mathrm{D}_{8}$ afforded 7 as neon yellow crystals $(18 \mathrm{mg}$, $0.017 \mathrm{mmol}, 82 \%)$. The isolated crystals were of X-ray quality. ${ }^{1} \mathrm{H}$ NMR $\left(\mathrm{C}_{6} \mathrm{D}_{6}, 400 \mathrm{MHz}\right) \delta 7.77(\mathrm{~s}, 4 \mathrm{H}), 7.54\left(\mathrm{~d},{ }^{4} J_{\mathrm{HH}}=2 \mathrm{~Hz}, 4 \mathrm{H}\right)$, $7.50\left(\mathrm{~d},{ }^{4} J_{\mathrm{HH}}=2.9 \mathrm{~Hz}, 4 \mathrm{H}\right), 7.35-7.10(\mathrm{~m}, 10 \mathrm{H}$, aromatic protons on $\mathrm{BnO}), 6.65\left(\mathrm{~d},{ }^{4} J_{\mathrm{HH}}=2 \mathrm{~Hz}, 4 \mathrm{H}\right), 6.57\left(\mathrm{~d},{ }^{4} J_{\mathrm{HH}}=2.4 \mathrm{~Hz}, 4 \mathrm{H}\right)$, $4.92\left(\mathrm{~d},{ }^{2} J_{\mathrm{HH}}=13.2 \mathrm{~Hz}, 4 \mathrm{H}\right.$, methylene protons on $\left.\mathrm{BnO}\right), 4.55$ (d, ${ }^{4} J_{\mathrm{HH}}=12.7 \mathrm{~Hz}, 4 \mathrm{H}$, methylene protons on $\left.\mathrm{BnO}\right), 4.25(\mathrm{~s}, 2 \mathrm{H}$, $\mathrm{OH}), 2.13$ (s, 6H), 1.99 (s, 6H), 1.54 (s, 36H), 1.26 (s, 36H), 1.22 $(\mathrm{s}, 36 \mathrm{H})$. Anal. calcd for $\mathrm{C}_{120} \mathrm{H}_{156} \mathrm{~N}_{4} \mathrm{O}_{10} \mathrm{Zn}_{4}: \mathrm{C}, 69.42 ; \mathrm{H}, 7.57 ; \mathrm{N}$, 2.70. Found: C, 68.15; H, 7.86; N, 2.52.

Preparation of $\mathbf{Z n}\left(\mathbf{L}^{\prime}\right)_{2}$ (8). A $2 \mathrm{~mL}$ solution of $\mathbf{L}^{\prime}(20 \mathrm{mg}$, $0.057 \mathrm{mmol}, 1$ equiv.) in hexane and a $2 \mathrm{~mL}$ solution of diethyl zinc $(0.17 \mathrm{mmol}, 3$ equiv.) in hexane were prepared and cooled to $-33{ }^{\circ} \mathbf{C}$. The chilled solution of $\mathbf{L}^{2}$ was then added dropwise to a stirring solution of the chilled diethyl zinc, producing a neon yellow-green solution. The reaction mixture was stirred for 1 hour, upon which the volatiles were removed in vacuo to afford the pure product as a neon yellow-green solid $(17 \mathrm{mg}$, $0.022 \mathrm{mmol}, 78 \%$ ). X-ray quality crystals were obtained from a saturated ether solution of 8 at $-33{ }^{\circ} \mathrm{C}$; the complex cocrystallized with one molecule of ether molecule per one molecule of 8. ${ }^{1} \mathrm{H}$ NMR $\left(\mathrm{C}_{6} \mathrm{D}_{6}, 400 \mathrm{MHz}\right) \delta 7.73\left(\mathrm{~d},{ }^{4} J_{\mathrm{HH}}=2.4 \mathrm{~Hz}\right.$, $2 \mathrm{H}), 7.48(\mathrm{~s}, 2 \mathrm{H}), 6.65\left(\mathrm{~d},{ }^{4} J_{\mathrm{HH}}=2.9 \mathrm{~Hz}, 2 \mathrm{H}\right), 6.61(\mathrm{~s}, 4 \mathrm{H}), 2.36(\mathrm{~s}$, 6H), $2.13(\mathrm{~s}, 6 \mathrm{H}), 1.73(\mathrm{~s}, 18 \mathrm{H}), 1.30(\mathrm{~s}, 18 \mathrm{H}), 1.11(\mathrm{~s}, 6 \mathrm{H}) ;{ }^{13} \mathrm{C}\left\{{ }^{1} \mathrm{H}\right\}$ NMR $\left(\mathrm{C}_{6} \mathrm{D}_{6}, 100 \mathrm{MHz}\right) \delta 175.24,170.61,146.62,142.37,135.66$, 135.25, 131.47, 131.16, 131.12, 130.57, 129.43, 129.24, 117.74, $35.99,34.07,31.63,30.12,20.81,18.95,17.40$. Anal. calcd for $\mathrm{C}_{48} \mathrm{H}_{64} \mathrm{~N}_{2} \mathrm{O}_{2} \mathrm{Zn} \times \mathrm{C}_{4} \mathrm{H}_{10} \mathrm{O}: \mathrm{C}, 74.30 ; \mathrm{H}, 8.87 ; \mathrm{N}, 3.33$. Found: $\mathrm{C}$, 73.37; H, 8.44; N, 3.46 .

\section{Conflicts of interest}

There are no conflicts of interest to declare.

\section{Acknowledgements}

This work was supported by National Science Foundation (NSF) under grant number CHE-1349048. Compounds characterization was carried out at Lumigen Instrument Center at Wayne State University. 


\section{References}

1 Biological Inorganic Chemistry: Structure and Reactivity, ed. H. B. Gray, E. I. Stiefel, J. S. Valentine and I. Bertini, University Science Books, Sausalito, CA, 2007.

2 Homo- and Heterobimetallic Complexes in Catalysis: Cooperative Catalysis, Topics in Organometallic Chemistry, ed. P. Kalck, Springer International Publishing, Switzerland, 2016, vol. 59.

3 For selected recent reviews/editorials on the cooperative reactivity of bimetallics, see: (a) J. F. Berry and C. M. Thomas, Dalton Trans., 2017, 46, 5472-5473; (b) C. M. Thomas, Comments Inorg. Chem., 2011, 32, 14-38; (c) S. Matsunaga and M. Shibasaki, Chem. Commun., 2014, 50, 1044-1057.

4 (a) M. H. Chisholm, Pure Appl. Chem., 2010, 82, 1647-1662; (b) M. J.-L. Tschan, E. Brulé, P. Haquette and C. M. Thomas, Polym. Chem., 2012, 3, 836-851.

5 (a) R. E. Drumright, P. R. Gruber and D. E. Henton, Adv. Mater., 2000, 12, 1841-1846; (b) S. Slomkowski, S. Penczek and A. Duda, Polym. Adv. Technol., 2014, 25, 436-447; (c) S. Inkinen, M. Hakkarainen, A.-C. Albertsson and A. Södergård, Biomacromolecules, 2011, 12, 523-532; (d) C. K. Williams, Chem. Soc. Rev., 2007, 36, 1573-1580.

6 For selected reviews on lactide polymerization, see: (a) B. J. O'Keefe, M. A. Hillmyer and W. B. Tolman, Dalton Trans., 2001, 2215-2224; (b) O. Dechy-Cabaret, B. MartinVaca and D. Bourissou, Chem. Rev., 2004, 104, 6147-6176; (c) M. J. Stanford and A. P. Dove, Chem. Soc. Rev., 2010, 39, 486-494; (d) P. J. Dijkstra, H. Du and J. Feijen, Polym. Chem., 2011, 2, 520-527; (e) C. A. Wheaton, P. G. Hayes and B. J. Ireland, Dalton Trans., 2009, 4832-4846; (f) A. Sauer, A. Kapelski, C. Fliedel, S. Dagorne, M. Kol and J. Okuda, Dalton Trans., 2013, 42, 9007-9023.

7 For selected references on Zn-containing lactide polymerization catalysts, see: (a) B. M. Chamberlain, M. Cheng, D. R. Moore, T. M. Ovitt, E. B. Lobkovsky and G. W. Coates, J. Am. Chem. Soc., 2001, 123, 3229-3238; (b) C. K. Williams, L. E. Breyfogle, S. K. Choi, W. Nam, V. G. Young Jr, M. A. Hillmyer and W. B. Tolman, J. Am. Chem. Soc., 2003, 125, 11350-11359; (c) H. Wang and H. Ma, Chem. Commun., 2013, 49, 8686-8688; (d) S. Abbina and G. Du, ACS Macro Lett., 2014, 3, 689-692; (e) H. Wang, Y. Yang and H. Ma, Macromolecules, 2014, 47, 7750-7764; (f) Z. Mou, B. Liu, M. Wang, H. Xie, P. Li, L. Li, S. Li and D. Cui, Chem. Commun., 2014, 50, 11411-11414; $(g)$ C. Fliedel, V. Rosa, F. M. Alves, A. M. Martins, T. Avilés and S. Dagorne, Dalton Trans., 2015, 44, 12376-12387; $(h)$ T. Rosen, Y. Popowski, I. Goldberg and M. Kol, Chem.-Eur. J., 2016, 22, 11533-11536; (i) T. Ebrahimi, E. Mamleeva, I. Yu, S. G. Hatzikiriakos and P. Mehrkhodavandi, Inorg. Chem., 2016, 55, 9445-9453.

8 C. K. Williams, N. R. Brooks, M. A. Hillmeyer and W. B. Tolman, Chem. Commun., 2002, 2132.

9 (a) A. Thevenon, C. Romain, M. S. Bennington, A. J. P. White, H. J. Davidson, S. Brooker and C. K. Williams, Angew. Chem.,
Int. Ed., 2016, 55, 8680-8685; (b) P. D. Knight, A. J. P. White and C. K. Williams, Inorg. Chem., 2008, 47, 11711-11719.

10 M. Normand, T. Roisnel, J.-F. Carpentier and E. Kirillov, Chem. Commun., 2013, 49, 11692-11694.

11 W.-L. Kong and Z.-X. Wang, Dalton Trans., 2014, 43, 91269135.

12 S. Sun, K. Nie, Y. Tan, B. Zhao, Y. Zhang, Q. Shen and Y. Yao, Dalton Trans., 2013, 42, 2870-2878.

13 T. K. Saha, V. Ramkumar and D. Chakraborty, Inorg. Chem., 2011, 50, 2720-2722.

14 M. H. Thibault and F.-G. Fontaine, Dalton Trans., 2010, 39, 5688-5697.

15 Y. Wang and H. Ma, Chem. Commun., 2012, 48, 6729-6731. 16 A. B. Kremer, K. M. Osten, I. Yu, T. Ebrahimi, D. C. Aluthge and P. Mehrkhodavandi, Inorg. Chem., 2016, 55, 5365-5374.

17 (a) I. Yu, A. Acosta-Ramírez and P. Mehrkhodavandi, J. Am. Chem. Soc., 2012, 134, 12758-12773; (b) J. Fang, I. Yu, P. Mehrkhodavandi and L. Maron, Organometallics, 2013, 32, 6950-6956.

18 (a) A. Bheemaraju, J. W. Beattie, R. L. Lord, P. D. Martin and S. Groysman, Chem. Commun., 2012, 48, 9595-9597; (b) A. Bheemaraju, J. W. Beattie, E. G. Tabasan, P. D. Martin, R. L. Lord and S. Groysman, Organometallics, 2013, 32, 2952-2962; (c) J. W. Beattie, D. W. White, A. Bheemaraju, P. D. Martin and S. Groysman, Dalton Trans., 2014, 49, 7979-7986; (d) J. W. Beattie, D. J. SantaLucia, D. W. White and S. Groysman, Inorg. Chim. Acta, 2017, 460, 8-16.

19 (a) A. Bheemaraju, J. W. Beattie, Y. Danylyuk, J. Rochford and S. Groysman, Eur. J. Inorg. Chem., 2014, 34, 5865-5873; (b) R. L. Hollingsworth, A. Bheemaraju, N. Lenca, R. L. Lord and S. Groysman, Dalton Trans., 2017, 46, 56055616.

20 (a) A. Panunzi, F. Giordano, I. Orabona and F. Ruffo, Inorg. Chim. Acta, 2005, 358, 1217-1224; (b) K. S. A. Motolko, D. J. H. Emslie and H. A. Jenkins, Organometallics, 2017, 36, 1601-1608; (c) N. R. Andreychuk and D. J. H. Emslie, Angew. Chem., Int. Ed., 2013, 52, 1696-1699; (d) C. A. Cruz, D. J. H. Emslie, L. E. Harrington, J. F. Britten and C. M. Robertson, Organometallics, 2007, 26, 692-701; (e) S. Takano, D. Takeuchi, K. Osakada, N. Akamatsu and A. Shishido, Angew. Chem., Int. Ed., 2014, 53, 9246-9250; (f) S. Takano, D. Takeuchi and K. Osakada, Chem.-Eur. J., 2015, 21, 6209-16218.

21 (a) J. A. Bellow, M. Yousif and S. Groysman, Comments Inorg. Chem., 2016, 36, 92-122; (b) P. P. Power, J. Organomet. Chem., 2004, 689, 3904-3919.

22 (a) J. A. Bellow, P. D. Martin, R. L. Lord and S. Groysman, Inorg. Chem., 2013, 52, 12335-12337; (b) J. A. Bellow, D. Fang, N. Kovacevic, P. D. Martin, J. Shearer, G. A. Cisneros and S. Groysman, Chem.-Eur. J., 2013, 19, 12225-12228; (c) M. Yousif, A. C. Cabelof, P. D. Martin, R. L. Lord and S. Groysman, Dalton Trans., 2016, 45, 97949804; (d) M. Yousif, D. J. Tjapkes, R. L. Lord and S. Groysman, Organometallics, 2015, 34, 5119-5128; (e) J. A. Bellow, S. A. Stoian, J. Van Tol, A. Ozarowski, R. L. Lord and S. Groysman, J. Am. Chem. Soc., 2016, 138, 5531-5534. 
23 For selected examples of three-coordinate zinc complexes with alkoxide donors, see: (a) J. S. Lum, P. E. Chen, A. L. Rheingold and L. H. Doerrer, Polyhedron, 2013, 58, 218-228; (b) L. Makolski, K. Zelga, R. Petrus, D. Kubicki, P. Zarzycki, P. Sobota and J. Lewinski, Chem.-Eur. J., 2014, 20, 14790-14799; (c) D. J. Darensbourg, S. A. Niezgoda, J. D. Draper and J. H. Reibenspies, Inorg. Chem., 1999, 38, 1356-1359; (d) M. H. Chisholm, J. C. Gallucci, H. Yin and H. Zhen, Inorg. Chem., 2005, 44, 4777-4785; (e) M. S. Hill and P. B. Hitchcock, Dalton Trans., 2002, 4694-4702; $(f)$ G. Anantharaman and K. Elango, Organometallics, 2007, 26, 1089-1092; (g) P. Jochmann and D. W. Stephan, Chem.Eur. J., 2014, 20, 8370-8378; (h) M. M. Olmstead, M. P. P. Power and S. C. Shoner, J. Am. Chem. Soc., 1991, 113, 3379-3385.

24 J. A. Bellow, M. Yousif, D. Fang, E. G. Kratz, G. A. Cisneros and S. Groysman, Inorg. Chem., 2015, 54, 5624-5633.
25 (a) C. Zhang and Z.-X. Wang, Appl. Organomet. Chem., 2009, 23, 9-18; (b) M. Bouyhayia, Y. Sarazina, O. L. Casagrande Jr and J.-F. Carpentier, Appl. Organomet. Chem., 2012, 26, 681-688; (c) M. Huang, C. Pan and H. Ma, Dalton Trans., 2015, 44, 12420-12431; (d) D. J. Doyle, V. C. Gibson and A. J. P. White, Dalton Trans., 2007, 358-363; (e) J. Chen, L. Guo, P. Ji and W. Li, Polym. Bull., 2017, DOI: 10.1007/ s00289-017-2040-0; (f) D. J. Darensbourg, P. Rainey and J. Yarbrough, Inorg. Chem., 2001, 40, 986-993; $(g)$ S. Groysman, E. Sergeeva, I. Goldberg and M. Kol, Eur. J. Inorg. Chem., 2006, 2739-2745.

26 L. Clowes, M. Walton, C. Redshaw, Y. Chao, A. Walton, P. Elo, V. Sumerin and D. L. Hughes, Catal. Sci. Technol., 2013, 3, 152-160.

27 (a) T. Aide and S. Inoue, Acc. Chem. Res., 1996, 29, 39-48; (b) N. Ajella, J.-F. Carpentier, C. Guillaume, S. M. Guillaume, M. Helou, V. Poirier, Y. Sarazin and A. Trifonov, Dalton Trans., 2010, 39, 8363-8376. 